\title{
Quality assurance (QA) in international forest monitoring programmes: activity, problems and perspectives from East Asia and Europe
}

\author{
Marco FerRetTi ${ }^{1 *}$, Nils KÖNIG ${ }^{2}$, Pasi RAUTIO ${ }^{3}$, Hiroyuki SASE $^{4}$ \\ ${ }^{1}$ TerraData environmetrics, Via P.A. Mattioli 4, 53100 Siena, Italy \\ ${ }^{2}$ Nordwestdeutsche Forstliche Versuchsanstalt Grätzelstrasse 2, 37079 Göttingen, Germany \\ ${ }^{3}$ Finnish Forest Research Institute (METLA), Eteläranta 55, 96300 Rovaniemi, Finland \\ ${ }^{4}$ Acid Deposition and Oxidant Research Center 1182 Sowa, Nishi-ku, Niigata, 950-2144, Japan
}

(Received 13 August 2008; accepted 3 March 2009)

Keywords:

East Asia /

Europe /

forest monitoring /

quality assurance

Mots-clés :

Asie de l'Est /

Europe /

surveillance des forêts /

assurance qualité

\begin{abstract}
- The quality of monitoring is defined by its ability to provide data that (i) allow estimates of the status of the target resource with defined precision level, (ii) permit change detection with defined power, and (iii) are comparable through space and time. To achieve these requirements a Quality Assurance (QA) perspective is essential.

- To what extent QA was considered and data quality achieved in international forest monitoring programmes in East Asia and Europe? What is missing?

- Past and present QA activity in forest monitoring in East Asia and Europe revealed that most attention was given to evaluate and promote comparability of measurements, with special emphasis on analytical chemistry. Much less attention was given to field sampling and to the overall monitoring design. QA approaches were unbalanced among the various investigations, and several problems with data comparability remained over years.

- Despite considerable work on data quality control, parts of the monitoring process are still poorly covered by QA and revealed weaknesses in design and implementation. More comprehensive, formal and stringent QA procedures are necessary in international monitoring initiatives. Steps currently being undertaken for a more comprehensive QA approach are presented.
\end{abstract}

Résumé - L'assurance qualité (AQ) dans les programmes de surveillance des forêts : activités, problèmes et perspectives pour l'Asie de l'Est et l'Europe.

- La qualité de la surveillance est définie par sa capacité à fournir des données qui (i) permettent des estimations de l'état de la ressource cible, définie à un niveau de précision, (ii) permettent la détection des changements de puissance définie et (iii) sont comparables à travers l'espace et le temps. Pour satisfaire à ces exigences d'assurance qualité (QA) la perspective est essentielle.

- Dans quelle mesure l'assurance qualité a été examinée de même que la qualité des données obtenues dans les programmes internationaux de surveillance des forêts en Asie de l'Est et l'Europe ? Qu'est-ce qui manque?

- L'activité passée et présente dans l'assurance qualité de surveillance des forêts en Asie de l'Est et Europe a révélé que la plus grande attention a consisté à évaluer et promouvoir la comparabilité des mesures, avec un accent particulier sur la chimie analytique. Beaucoup moins d'attention a été accordée à l'échantillonnage sur le terrain et au modèle de surveillance globale. Les approches de QA ont été déséquilibrées entre les différentes enquêtes, et plusieurs problèmes avec la comparabilité des données sont restés au fil des années.

- Malgré un travail considérable sur la qualité des données de contrôle, des parties du processus de suivi sont encore mal couvertes par l'assurance qualité et des lacunes de conception et de mise en œuvre ont été révélées. Des procédures d'assurance qualité plus complètes, structurées et rigoureuses sont nécessaires dans les initiatives internationales de surveillance. Les étapes actuellement entreprises pour une approche plus globale d'assurance qualité sont présentées.

\footnotetext{
*Corresponding author: ferretti@terradata.it
} 


\footnotetext{
"The results of inadequate monitoring can be both misleading and dangerous not only because of their inability to detect ecologically significant changes, but also because they create the illusion that something useful has been done" (Peterman, 1990)
}

\section{INTRODUCTION}

\subsection{The need for quality assurance}

There is a general agreement that monitoring is essential to obtain information about the condition of natural resources, its development in time and space, and to study its relationships with biotic/abiotic factors (Ferretti, 1997; 2004; Stevens, 1994). At the same time, considerable concern exists in the scientific community about the ability of monitoring programmes to provide the desired information (Legg and Nagy, 2006; Vos et al., 2000). The main reason for this is the poor confidence about the quality of the data, with most typical questions concerning the statistical basis of sampling design, the reliability and comparability of data, and data management (Elzinga et al., 2001; Ferretti, 2009; Legg and Nagy, 2006; Shampine, 1993; Vos et al., 2000; Wagner, 1995). This concern is justified especially for terrestrial monitoring with a large-scale coverage and a long-term nature, such as the international monitoring programmes. On one hand, the large scale coverage requires a high number of field observers (Cozzi et al., 2002), laboratories and instruments (Mosello et al., 2001) and this implies possible problems for data comparability across space. While this kind of problem may always occur with terrestrial monitoring over large areas (remote sensing techniques may be less influenced), they are exacerbated in international programmes when a joint effort of experienced institutions over several countries is necessary. On the other hand, the time "impacts how the work is viewed by the people collecting data, as well as the people who ultimately will use the data" (Shampine, 1993). In addition, change in personnel (in particular under the current labour market conditions) and change in methods (due to conceptual and technical improvement of methods, techniques and instruments) may lead to comparability problems at times of personnel/method changes.

There is an agreement that the quality of the monitoring can be evaluated in terms of its ability to provide data good enough to allow quantitative assessment of status and change/trend of the attribute of concern over the population of interest (e.g. Elzinga et al., 2001). Such an ability is related to a number of issues, but above all there are two major sets of requirements to be considered. A first set regards the statistical design of the monitoring, and a second one the precision and accuracy of the measurements. The former controls the ability of monitoring to provide precise estimates of status and effective detection of changes. The latter controls the reliability and comparability of measurements through time and space. A quality assurance (QA) system, i.e. "the organisational structure, the processes and procedures necessary to ensure that the overall intentions and direction of an organisation as regards quality are met and that the quality of the product or service is assured"
(ISO) allows driving the monitoring design to ensure that the above requirements are met. Even though QA issues are nothing new in forest monitoring (e.g. Cline and Burkman, 1989; Innes, 1993), the extent to which a QA framework was adopted in designing and implementing international forest monitoring programmes is uncertain.

\subsection{Monitoring objectives, design and results}

Since the quality of monitoring depends on its ability to quantify status and change of a given resource, expectation in these respects must be specified without ambiguity by monitoring objectives. The connection among objectives, design and results is clear when considering that quantifying status and changes require monitoring data (i) to allow estimates with known and documented precision of the population's parameter of interest for the attribute of concern; and (ii) to be able to detect change and trends of the variable of concern over defined time windows with and known confidence. Thus, to be succesfull, monitoring should be designed to fit the above requirements, and this is only possible if they are formally defined by the monitoring objectives. Two examples will suffice. The precision of the estimate can be expressed in terms of the width of confidence interval in relation to the value of the estimate (e.g. confidence interval calculated for $P=95 \%$ should not be larger than $10 \%$ of the value of the estimate) and depends very much on the sampling design. Thus, when an expected precision level is set by monitoring objectives, sampling is designed to minimize sampling error by acknowledging the inherent characteristics of the population of concern (extent, variability, spatial arrangement) and identifying the adequate sampling scheme (allocation of sampling units over the population of concern) and sample size (number of sampling units). Although different inferential approaches exists (e.g., model-based and design-based, see Stevens, 1993), the design-based approach offers considerable advantages. It is worth noting that sample size and parameter estimators varies with the sampling scheme. Several textbooks exist that may help in this respect (e.g. Cochran, 1977).

Change detection is of particular interest for monitoring. Implicitly, almost any attempt to detect change is an hypothesis testing exercise, with the null hypothesis being no change occurring. However, to some extent, change is inherent to forest ecosystems, and the interest is therefore to detect those changes exceeding some limits, say "acceptable" limit. When the hypothesis testing is of concern, the statistical power (power $=1.0$ minus the probability of a Type II error) of the test becomes important (for a discussion about Type I and Type II errors see e.g. Di Stefano, 2003; Field et al., 2004; Mapstone, 1995; Peterman, 1990). However, the power 


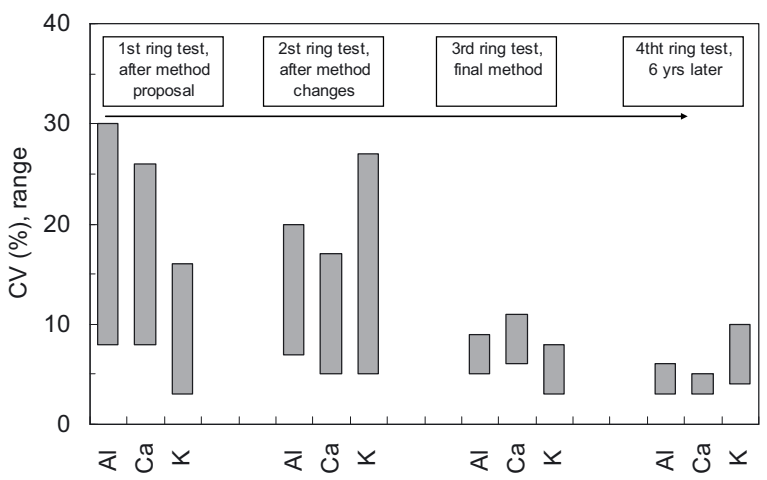

Figure 1. Ranges of coefficients of variation (\%) in 4 ring tests 1997 2007 for the elements $\mathrm{Ca}, \mathrm{Al}$ and $\mathrm{K}$; total digestion method (ring tests with 6-10 humus and soil samples; 13-18 participating laboratories).

depends on effect size (the change the monitoring is requested to detect), survey design and statistical test applied, sample size and the Type I error rate. Again, all these details should be specified taking into account the expectation set by the objectives. A frequent problem is that monitoring objectives often omit to report the precision level required and - even more frequently - no statement is made about acceptable change, minimum detectable change and the power that the monitoring should have in change detection analysis (Legg and Nagy, 2006).

\subsection{Data quality and monitoring results}

Besides sampling design, the control of measurement error is an important issue for monitoring programmes. Although it refers to a national exercise, the example of the German soil survey is useful to elucidate the benefits arising from a QA perspective when several laboratories are involved in the same investigation. In 1989, the heads of the German forestry research laboratories formed a working group to ensure the comparability of analytical data of the German Soil Survey and their evaluation (König and Wolff, 1993). The comparability of concentration data was clearly improved after comparison of digestion methods, with a subsequent joint development of a total digestion method, together with the unambiguous specification of methods to be used (Fig. 1). Furthermore, error sources during the different stages of the analyses were identified by a newly developed ring-test method that permitted to evaluate separately each analytical step. By this way, the influence of the different analytical measurement methods was obvious: for some elements, differences in results arose from two measurement techniques (inductively coupled plasma spectrometer, (ICP) or atomic absorption spectrometer, AAS) and not from problems with the digestion method.

Another question with measurement error is its impact on change/trend detection. While the power of the statistical test is essential in detecting temporal changes in ecosystem attributes, such an ability can, however, be blurred by the imprecision of the data. The importance of data quality on trend detection was highlighted in a recent study by Sulkava et al. (2007) who made both theoretical computations and computations using results of "Needle/Leaf Interlaboratory Comparisons Tests" conducted by Forest Foliar Coordinating Centre of ICP Forests (in co-operation with European Commission). Their results showed that, when harmonized method is assumed to reduce the variability due to sampling, poor quality of the instrumental analysis blurs the data to the extent that the ability to detect trends is lost. Considering that the actual change in the data (i.e., sulphur concentrations in pine needles) took place within $15 \mathrm{y}$, delay in detecting this kind of change would affect the whole meaning of monitoring, with an impact remaining undetected, and a wrong message to policy makers.

\subsection{Objectives of the paper}

Much concern in the past was devoted to data quality in national forest monitoring programmes (e.g. US FHM, see Palmer, 1992; national forest inventories in Italy, Japan, Switzerland and USA, see Gasparini et al., 2009; Kitahara et al., 2008; Kaufmann and Schwyzer, 2001; Pollard et al., 2006). In this paper we considered Quality Assurance (QA) issues in two major international monitoring initiatives: the UN/ECE International Co-operative Programme on Assessment and Monitoring Air Pollution Effects on Forests (ICPForests) in Europe and the Acid Deposition Monitoring Network in East Asia (EANET). It is worth noting that these two programmes are just examples of a variety of other international monitoring initiatives (e.g. Parr et al., 2002). We will report about QA/QC components and activity carried out within the UN/ECE ICP-Forests and the EANET and discuss recent progress in order to suggest a possible way ahead.

\section{METHODS}

\subsection{Monitoring programmes considered}

The ICP-Forests (developed under the United Nation Convention on Long-Range Transboundary Air Pollution) has been implemented since 1986. Now the programme includes ca. 6000 plots for largescale forest condition monitoring (so-called Level I) and ca. 800 plots for intensive forest ecosystem monitoring (Level II) distributed across 41 participating countries (UN/ECE, 2007).

The acid deposition monitoring network in East Asia (EANET) started its preparatory-phase activities with ten participating countries in East Asia - China, Indonesia, Japan, Malaysia, Mongolia, the Philippines, Republic of Korea, Russia, Thailand and Viet Nam in 1998. The EANET began its regular-phase activities in January 2001 and now comprises 13 participating countries including Cambodia, Lao PDR, and Myanmar. Its monitoring programme consists of monitoring of wet deposition at 50 sites, dry deposition at 40 sites, inland aquatic environment at 11 lake catchments and 5 rivers, and forest soil and forest vegetation at 25 forest plots in 17 areas.

\subsection{Review and evaluation of the QA activity}

Information about QA activity was obtained from different source: manuals of the ICP-Forests and EANET (Tab. I), internal reports of 
Table I. Overview of the subject covered by the Manuals and guidelines adopted by the ICP-Forests and the EANET.

\begin{tabular}{ll}
\hline ICP-Forests & EANET \\
\hline Visual assessment of crown condition & Guidelines for acid deposition monitoring \\
Sampling and analysis of soil & Technical manual for wet deposition monitoring in East Asia \\
Methods for soil analysis & QA/QC program for wet deposition monitoring in East Asia \\
Soil solution collection and analysis & Technical manual for monitoring on inland aquatic environment in East Asia \\
Sampling and analysis of needles and leaves & QA/QC program for monitoring on inland aquatic environment in East Asia \\
Estimation of growth and yield & Technical manual for soil and vegetation monitoring in East Asia \\
Sampling and analysis of deposition & QA/QC program for soil and vegetation monitoring in East Asia \\
Meteorological measurements & Data reporting procedures and formats for acid deposition monitoring in East Asia \\
Assessment of ground vegetation & QA/QC program for the air concentration monitoring in East Asia \\
Phenological observations & Technical document for filter pack method in East Asia \\
Monitoring of air quality & Sub-manual on forest vegetation monitoring in EANET \\
Assessment of ozone injury & \\
Sampling and analysis of litterfall & \\
\hline
\end{tabular}

the two programmes, and papers published on peer reviewed journals. Reference will be given as appropriate. Results are reported in terms of QA elements adopted by the two programmes, nature (field sampling, field measurements, laboratory analysis) and coverage (investigations, years, countries and labs involved) of QA/QC activity. Examples of possible QA problems as identified in manuals and exercises, lack of QA coverage and inconsistencies are given alongside.

\section{RESULTS}

\subsection{QA in the ICP-Forests in Europe}

\subsubsection{Main QA components}

Early attempts in taking care of data quality in the UN/ECE ICP-Forests programme can be traced back to 1987, when the first version of the ICP-Forests manual was prepared and the field intercalibration exercises for crown condition assessment were organized. Although not consistently structured, five main QA components may be identified within the ICPForests:

(i) The Expert Panels, groups of experts that are in charge for developing, reviewing and updating methods for the different investigations, to identify data quality requirements, and avenues for data analysis (http://www. icp-forests.org/BodStruc.htm);

(ii) The SOPs (Standard operating procedures) reported in the ICP-forests manual, that now has different sections (http://www.icp-forests.org/Manual.htm), each dealing with a specific investigation (Tab. I). The Manual describes field sampling methods, measurement methods and data reporting rules. Manuals dealing with chemical analysis also cover method regulation for extraction and digestion methods, selection of suitable methods for element detection, ring tests and tolerable limits, use of reference material and control charts, quality checks for analytical data, and analytical info sheets (http://www.icp-forests.org/WGqual_lab.htm). Tolerable ring test limits were identified and continuously reviewed. (iii) The intercalibration exercises for field measurements and ring-tests for laboratory measurements. These are a tool for improving the quality of the data produced by the participants (observers, laboratories) over time. Besides crown condition intercalibration exercises, other quality control initiatives aimed at comparing results obtained from different agencies/countries started during the 1990s (Tab. II).

(iv) The ICP-forests helping programme for laboratories with analytical problems. Close cooperation between these laboratories and laboratories with good laboratory practices is considered to be an effective way of improving laboratory proficiency. The assistance consist of a few days visit to the laboratory, as well as a return visit, in order to identify easily detectable problems in laboratory organization and/or specific analytical processes.

(v) The Working group QA/QC in laboratories (QA-QC $\mathrm{Lab}$ ), which covers all aspects related to chemical analyses within the ICP-forests (http://www.icp-forests.org/ WGqual_lab.htm)

Today every investigation carried out within the ICP-forests is covered by some QA/QC activity. In general, laboratory measurements and data transmission rules are well covered, while much less attention has been paid in providing sound instructions for effective sampling design, to field measurements and to set unambiguous objectives. In addition, huge difference exists within and between sections of the manual and this asks for an harmonization effort of the QA/QC activity.

\subsection{2. $Q A / Q C$ activity in field sampling methods}

Little formal activity was carried out to compare sampling designs under field condition and to estimate their effect on monitoring results. Most information can be obtained from questionnaires (e.g. Cozzi et al., 2002; http://www.icp-forests. org/EPbiodiv.htm) and only one formal exercise at international level was carried out (deposition sampling, see Draijers et al., 2001). Considerable differences were reported for target population, plot type and sample trees selection for crown 
Table II. Overview and timing of the intercalibration-intercomparison activity carried out within the ICP-Forests since it was launched in 1985 up to 2007. In brackets: informal exercises. The symbol + identified exercises carried out within ICP-Forests; the symbol $\S$ indicates the exercises to which ICP Forests labs took part, but that were organized within different projects (AQUACON-MedBas Subproject No. 6 and "Acid rain" and Subproject No. 7 "Freshwater"); the symbol * indicates the depositon sampling intercomparison exercise, actually carried out between October 1999 and April 2000 (Draijers et al., 2001).

\begin{tabular}{|c|c|c|c|c|c|c|c|c|c|}
\hline \multirow{2}{*}{ Reference year } & \multicolumn{5}{|c|}{ Field-based measurements } & \multicolumn{4}{|c|}{ Chemical-physical measurements } \\
\hline & $\begin{array}{c}\text { Crown } \\
\text { condition }\end{array}$ & $\begin{array}{l}\text { Tree } \\
\text { growth }\end{array}$ & $\begin{array}{c}\text { Ground } \\
\text { vegetation }\end{array}$ & $\begin{array}{c}\text { Tree } \\
\text { phenology }\end{array}$ & $\begin{array}{l}\text { Ozone visible } \\
\text { foliar injury }\end{array}$ & $\begin{array}{c}\begin{array}{c}\text { Foliar } \\
\text { analysis }\end{array} \\
\text { and }\end{array}$ & $\begin{array}{c}\text { Soil } \\
\text { chemistry }\end{array}$ & $\begin{array}{l}\text { Deposition } \\
\text { chemistry }\end{array}$ & Meteorology \\
\hline 1985 & & & & & & & & & \\
\hline 1986 & & & & & & & & & \\
\hline 1987 & + & & & & & & & & \\
\hline 1988 & + & & & & & & & & \\
\hline 1989 & + & & & & & & & & \\
\hline 1990 & + & & & & & & & & \\
\hline 1991 & + & & & & & & + & & \\
\hline 1992 & + & & & & & & & & \\
\hline 1993 & + & & & & & + & & & \\
\hline 1994 & + & & & & & & + & & \\
\hline 1995 & + & & & & & + & & & \\
\hline 1996 & + & & & & & & & $\S$ & \\
\hline 1997 & + & & & & & + & & $\S$ & \\
\hline 1998 & + & & & & & & & $\S$ & \\
\hline 1999 & + & & & & & + & & $*$ & \\
\hline 2000 & + & & & & + & & & $\S$ & \\
\hline 2001 & + & & & & + & + & & & \\
\hline 2002 & + & & & & + & & + & + & \\
\hline 2003 & + & & & & + & + & & & \\
\hline 2004 & + & & $(+)$ & & + & + & & & \\
\hline 2005 & + & & & & + & + & + & + & \\
\hline 2006 & + & & & $(+)$ & + & + & & & \\
\hline 2007 & + & & & & + & + & + & & \\
\hline
\end{tabular}

condition assessment in Level I plots (Cozzi et al., 2002), sampling design for assessment of ground vegetation on Level II plots (http://www.icp-forests.org/EPbiodiv.htm, Tab. III) and design and number of collectors, and sampling scheme for deposition on Level II plots (Bleeker et al., 2003; Draijers et al., 2001; Erisman et al., 2003). Sampling issues have also been investigated for the Level I network (crown condition assessment, Köhl et al., 1994) and for individual Level II plots (soil variables: Kirvan et al., 2005; deposition: Houston et al., 2002) and reviewed by Thimonier (1998) for deposition.

\subsection{3. $Q A / Q C$ for field surveys}

Since 1987, the core of QA/QC activity for field surveys was the comparison of tree crown condition assessment (Tab. II) that has been carried out in a series of international exercises held throughout Europe. Soon after the initiation of ICP-forests it becames obvious that there was an high degree of variation among countries mostly due to differences in assessment methods and reference standards (Cozzi et al., 2002; Dobbertin et al., 1997; Innes et al., 1988; 1993). More recently, a new format of international intercomparison exercises was developed, the International cross-comparison courses (ICCs, Ferretti and Mues, 2002) within which crews returned on the sample plots at time interval in order to allow not only the evaluation of data comparability among different crews, but also their ability to consistently observe time changes. However, even recent results from ICCs revealed that a considerable number of significant differences still exists between national reference teams from several countries and under several assessment conditions (Mizoue and Dobbertin, 2003; Mues, 2005). Several international training and intercalibration exercises were also carried out for the assessment of visible ozone injury (e.g., Bussotti et al., 2003; 2006) (Tab. II). Again, large and significant differences were observed among field crews from different countries. To our knowledge, no formal exercise has been carried out to compare tree growth measurements accuracy, ground vegetation and phenology assessment. In addition, no formal data quality objectives (DQOs) were identified for most of field surveys, and this limit the possibility for an evaluation of data quality and its monitoring over time.

\subsection{4. $Q A / Q C$ for laboratories}

Several exercises were undertaken to compare chemical measurements performed within the ICP-Forests (Tab. II). For example, 10 foliage, 5 soil and 2 water ring tests were implemented and evaluated from 1991 to date (Tab. IV). Over the years, more than 90 laboratories have been involved in the 
Table III. Main monitoring methods for ground vegetation adopted by countries participating in the ICP-forests. For each method, number of countries, number of plot per country (range), number of field crews per country (range), number of subplots per plot (range) and size of subplot (range) are reported (compiled after: Anonymous, " ground vegetation survey in the ICP Forest level II plots in all countries", available on the official web site of the ICP-Forests, National http://www.icp-forests.org/EPbiodiv.htm.). Note: one country may adopt more than one method.

\begin{tabular}{|c|c|c|c|c|c|}
\hline $\begin{array}{l}\text { Assessment } \\
\text { method }\end{array}$ & $\begin{array}{c}\text { No of } \\
\text { countries }\end{array}$ & $\begin{array}{l}\text { Plots per country, } \\
\text { range }(n)\end{array}$ & $\begin{array}{l}\text { Crews per country, } \\
\text { range }(n)\end{array}$ & $\begin{array}{l}\text { Subplots per plot, } \\
\text { range (n) }\end{array}$ & $\begin{array}{l}\text { Size of subplot, } \\
\text { range }\left(\mathrm{m}^{2}\right)\end{array}$ \\
\hline Coverage & 13 & $1-53$ & $1-17$ & $1-200$ & $0.25-2500$ \\
\hline Braun-Blanquet & 9 & $7-15$ & $1-17$ & $1-24$ & $75-400$ \\
\hline Contact point & 3 & $3-8$ & $1-3$ & $8-24$ & $0.5-1$ \\
\hline
\end{tabular}

Table IV. Details about number of countries and laboratories participating to the ICP-Forests ring-tests for labs since the ICP-Forests was launched in 1985 (after Cools et al., 2007; Fürst, 2008; Marchetto et al., 2006; Mosello et al., 1997; 1998; 1999; 2001; 2002; Mues, 2006). The symbol * indicates the number of countries and labs (=sampling systems) that participated to the depositon sampling intercomparison exercise (Draijers et al., 2001). § Indicates the exercises to which ICP Forests labs took part, but that were organized within different projects (AQUACON-MedBas Subproject No. 6 and "Acid rain" and Subproject No. 7 "Freshwater").

\begin{tabular}{|c|c|c|c|c|c|c|c|c|c|}
\hline \multirow{2}{*}{$\begin{array}{l}\text { Reference } \\
\text { year }\end{array}$} & \multicolumn{3}{|c|}{ Foliar analysis } & \multicolumn{3}{|c|}{ Soil (solid phase) analysis } & \multicolumn{3}{|c|}{ Water analysis (deposition and soil solution) } \\
\hline & Exercise, No. & Countries, $n$ & Labs, $n$ & Exercise, No. & Countries, $\mathrm{n}$ & Labs, $\mathrm{n}$ & Exercise, No. & Countries, $\mathrm{n}$ & Labs, $\mathrm{n}$ \\
\hline 1985 & & & & & & & & & \\
\hline 1986 & & & & & & & & & \\
\hline 1987 & & & & & & & & & \\
\hline 1988 & & & & & & & & & \\
\hline 1989 & & & & & & & & & \\
\hline 1990 & & & & & & & & & \\
\hline 1991 & & & & 1 & 22 & 22 & & & \\
\hline 1992 & & & & & & & & & \\
\hline 1993 & 1 & 21 & 24 & & & & & & \\
\hline 1994 & & & & 2 & 25 & 26 & & & \\
\hline 1995 & 2 & 25 & 39 & & & & & & \\
\hline 1996 & & & & & & & & $14 \S$ & $18 \S$ \\
\hline 1997 & 3 & 29 & 51 & & & & & $13 \S$ & $40 \S$ \\
\hline 1998 & & & & & & & & $20 \S$ & $53 \S$ \\
\hline 1999 & 4 & 29 & 52 & & & & & $20 *$ & $17 *$ \\
\hline 2000 & & & & & & & & $20 \S$ & $42 \S$ \\
\hline 2001 & 5 & 29 & 53 & & & & & & \\
\hline 2002 & & & & 3 & 27 & 52 & 1 & 27 & 59 \\
\hline 2003 & 6 & 26 & 46 & & & & & & \\
\hline 2004 & 7 & 23 & 43 & & & & & & \\
\hline 2005 & 8 & 30 & 52 & 4 & 28 & 52 & 2 & 27 & 52 \\
\hline 2006 & 9 & 28 & 53 & & & & & & \\
\hline 2007 & 10 & 29 & 54 & 5 & 29 & 48 & & & \\
\hline
\end{tabular}

different ring tests. Results revealed the benefit arising from this kind of exercises. The percentage of non tolerable results in the needle/leaf ring tests decreased during the last 8 years (Fig. 2) (Fürst, 2008). The results of the 2005 working ring test (WRT, 2005) for deposition and soil solution samples were much better then those from the WRT 2002 (Fig. 3) (Marchetto et al., 2006). Controversial results were obtained for soil (solid phase): in the 5th soil ring test the CV (coefficient of variation) has improved for some variables (particle size distribution, carbonates, total nitrogen, exchangeable cations and aqua regia extracable elements), but remained at the same level or was even worse for other ( $\mathrm{pH}$, organic carbon and acid oxalate extractable Fe and Al) (Tab. V). This is only a very rough comparison since it concerns the average of different soil samples and the CV largely depend on the kind of sample. When a comparable sample was used, as it was done in the 4th and 5th ring-test, a decrease of the coefficient of variation was obvious (see Cools et al., 2007 for details). Great differences may also occur between laboratories with respects to their internal QA methods and quality checks. For example, control charts were used by $49 \%$ of the participating laboratories in the WRT 2005 (Marchetto et al. 2006), and by $98 \%$ of the participating laboratories in the needle/leaves ring test 2008 (Fürst, 2008).

The interlaboratory tests helped laboratories to identify possible problems in their methods and the tests were used to undertake actions to improve the quality or to reject unsuitable methods. In some cases problems were solved by exchanging experience, visits in and training with other labs. In some other 


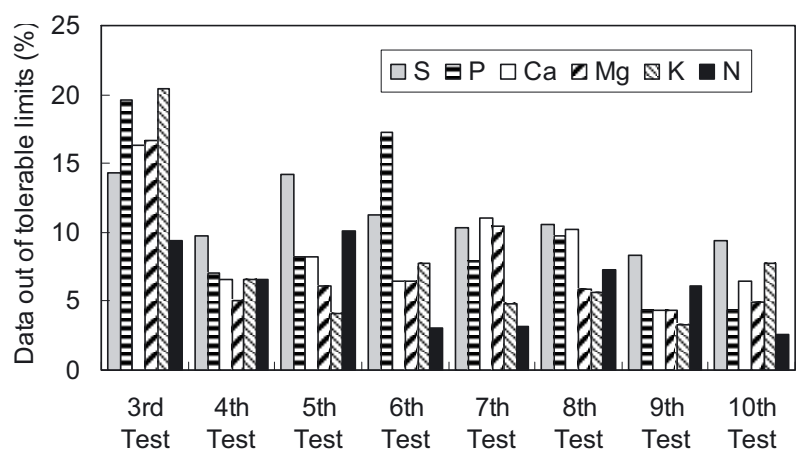

Figure 2. Progress in data quality reported as percentage of non tolerable results (by courtesy of Alfred Fürst, see also http://www.waldwissen.net/themen/inventur_monitoring/ oekosystemmonitoring/bfw_ringtest_2009_DE). Tolerable limits are set by ICP-forests (expert panel on foliage and litterfall) and have been tightened during the course of time. For example, for $\mathrm{N}$ the limit has been $10 \%$ deviation from the mean in the ring test from 1999 onwards (for other elements see Fürst, 2008). See Table IV for details about the tests.

cases, recommendations were made to abandon certain methods formerly suggested in the Manual.

\subsection{QA in EANET}

\subsubsection{QA components}

The regular-phase monitoring activity of EANET started in 2001 and is conducted according to the Guidelines, Technical Manuals/Documents and the QA/QC Programmes, which are continuously reviewed and updated (EANET, 2006; Task Force on Soil and Vegetation Monitoring of EANET, 2006) (Tab. I). The QA/QC programme in EANET cover all activities from site selection to data reporting. The main components in EANET QA/QC programmes include:

(i) Development of national QA/QC programs. Each participating country should develop its own $\mathrm{QA} / \mathrm{QC}$ programs taking national conditions into consideration.

(ii) Clear assignment of responsibility. A national QA/QC manager is designated in each country to assist the network manager in implementing the monitoring activities. Personnel in charge of data management and reporting should also be appointed in the respective laboratories and/or organizations in charge of field surveys.

(iii) Development of SOPs. SOPs are the procedures to be used in the monitoring, in the field, laboratory, and data management areas. Based on the technical manuals and QA/QC programs listed in Table I, the laboratories and field-survey organizations should prepare their own SOPs that meet actual conditions of respective laboratories/organizations. The SOPs should be sufficiently specific and easy to understand for analysts and surveyors.

(iv) Data quality objectives (DQOs). The DQO values define the desirable levels of accuracy and precision of the measurements. They varies according to the investigation: for

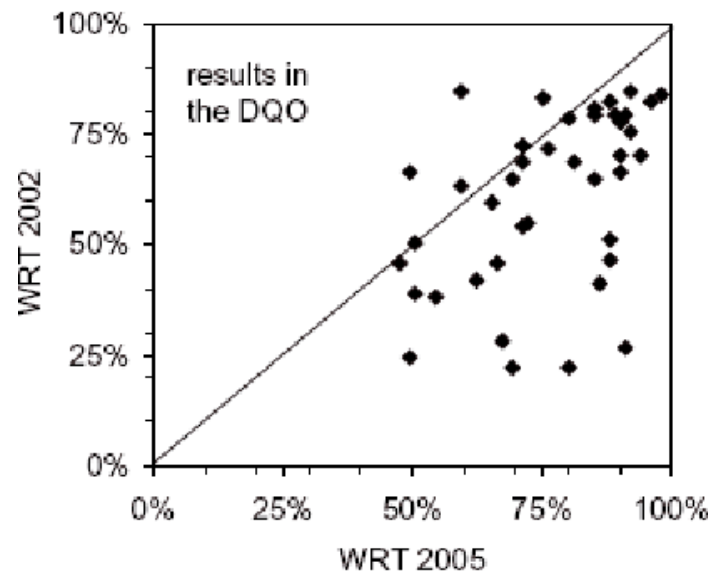

Figure 3. Frequency (\%) of results falling within the DQOs for each laboratory participating in the working ring test for deposition and soil solution samples in 2002 and 2005 (after Marchetto et al., 2006). See Marchetto et al., 2006 for DQOs.

example, required DQO for wet deposition and inland aquatic environment are $15 \%$ of deviation from prepared value (Network Center for EANET, 2006).

(v) Training programmes. According to the QA/QC programmes (EANET, 2006), EANET has conducted three training courses for surveyors and analysts who are working for the national centers and relevant organizations. The Japan international cooperation agency (JICA), in cooperation with EANET, conducted the 3rd country training programme in Thailand (two weeks) and the JICA training course on EANET in Japan (ten weeks) to provide training on acid deposition and air quality management. Acid deposition and oxidant research center (ADORC) as Network Center (NC) conducted also the Individual Training Course (four weeks).

(vi) Inter-laboratory comparison projects. The interlaboratory comparison projects of EANET have been carried out by $\mathrm{NC}$ for wet deposition, soil, inland aquatic environment, and for dry deposition (filter pack method) (Tabs VI, VII). As for the project on soil, the data submitted to NC were statistically analyzed and the inter-laboratory precision was calculated as coefficient of variation $(\mathrm{CV}, \%)$.

(vii) Audit to sites and laboratories by the national centres. The audit includes field training, advice on sample handling and analysis, check of analytical instruments, and information exchange of QA/QC activities in the laboratories. In case of forest soil monitoring in Japan, experts visit to forest plots managed by local governments every five years (i.e., the soil sampling interval) to check sampling and analytical procedures in the respective plots and laboratories.

(viii) Data control and reporting. Data are checked by the respective laboratories. In case of wet deposition and inland aquatic environment, ion balances and theoretical values of the electric conductivity are assessed for all measured data. The data is checked again and compiled 
Table V. Group CV's (coefficient of variation, \%) of the 2nd, 3rd, 4th and 5th soil ring test by Forest soil coordinating centre (FSCC), after elimination of the outliers (after Cools et al., 2007).

\begin{tabular}{|c|c|c|c|c|}
\hline & 2nd FSCC RT & 3rd FSCC RT & 4th FCSCC RT & 5th FSCC RT \\
\hline Group 1: Particle size distribution & NA & 53 & 37 & 23 \\
\hline Group 2: $\mathrm{pH}$ & 3.25 & 3.5 & 3.1 & 3.2 \\
\hline Group 3: Carbonate content & NA & 206 & 129 & 45 \\
\hline Group 4: Organic carton & 41.5 & 18 & 13 & 16 \\
\hline Group 5: Total N & 25 & 17 & 27 & 17 \\
\hline Group 6: Exchangeable cations & 52 & 71 & 54 & 49 \\
\hline Group 7: Aqua regia extractable elements & 35 & 47 & 33 & 26 \\
\hline Group 8: Total elements & & 21 & & 9 \\
\hline Group 9: Acid Oxalate extractable Fe \& Al & NA & 44 & 12 & 20 \\
\hline
\end{tabular}

NA: not available.

Table VI. Overview and timing of the inter-laboratory comparison projects and field exercises carried out within the EANET since it was launched in 1998.

\begin{tabular}{|c|c|c|c|c|c|c|c|}
\hline \multirow[b]{2}{*}{$\begin{array}{l}\text { Reference } \\
\text { year }\end{array}$} & \multicolumn{4}{|c|}{ Inter-laboratory comparison projects } & \multicolumn{3}{|c|}{ Field exercises* } \\
\hline & $\begin{array}{l}\text { Wet deposition } \\
\text { (artificial } \\
\text { rainwater) }\end{array}$ & $\begin{array}{l}\text { Dry deposition } \\
\text { (impregnated filters for } \\
\text { the filter pack method) }\end{array}$ & $\begin{array}{c}\text { Soil } \\
\text { (soil or soil } \\
\text { extract solution) }\end{array}$ & $\begin{array}{c}\text { Inland aquatic } \\
\text { environment (artificial } \\
\text { inland water) }\end{array}$ & $\begin{array}{c}\text { Soil profile } \\
\text { description, and soil } \\
\text { sampling methods }\end{array}$ & $\begin{array}{c}\text { Observation } \\
\text { methods for } \\
\text { forest vegetation }\end{array}$ & $\begin{array}{c}\text { Sampling } \\
\text { methods for } \\
\text { inland waters }\end{array}$ \\
\hline 1998 & + & & & & + & + & + \\
\hline 1999 & + & & + & & + & + & + \\
\hline 2000 & + & & + & + & + & + & + \\
\hline 2001 & + & & + & + & + & + & + \\
\hline 2002 & + & & + & + & + & + & + \\
\hline 2003 & + & & + & + & + & + & + \\
\hline 2004 & + & & + & + & + & + & + \\
\hline 2005 & + & + & + & + & + & + & + \\
\hline 2006 & + & + & + & + & + & + & + \\
\hline 2007 & + & + & + & + & + & + & + \\
\hline
\end{tabular}

* Field exercises were carried out as a part of the JICA training course.

Table VII. Details about number of countries and laboratories participating to the EANET inter-laboratory and field exercises.

\begin{tabular}{|c|c|c|c|c|c|c|c|c|c|c|c|c|c|}
\hline Year & \multicolumn{3}{|c|}{ Wet deposition } & \multicolumn{3}{|c|}{ Dry deposition } & \multicolumn{3}{|c|}{ Soil } & \multicolumn{3}{|c|}{ Inland aquatic environment } & \multirow{2}{*}{$\begin{array}{c}\text { Field exercises } \\
\text { Trainees } \\
n\end{array}$} \\
\hline & $\begin{array}{c}\text { Sample } \\
n\end{array}$ & $\begin{array}{c}\text { Countries } \\
n\end{array}$ & $\begin{array}{c}\text { Labs } \\
N\end{array}$ & $\begin{array}{c}\text { Sample } \\
n\end{array}$ & Countries & $\begin{array}{c}\text { Labs } \\
n\end{array}$ & Sample & Countries & Labs & Sample & Countries & Labs & \\
\hline 1998 & 2 & 10 & 24 & & & & & & & & & & 8 \\
\hline 1999 & 2 & 10 & 21 & & & & 2 & 10 & 15 & & & & 8 \\
\hline 2000 & 2 & 10 & 24 & & & & 2 & 10 & 15 & 1 & 7 & 13 & 8 \\
\hline 2001 & 2 & 10 & 23 & & & & $2^{* *}$ & 10 & 16 & 1 & 8 & 14 & 10 \\
\hline 2002 & 2 & 10 & 24 & & & & 2 & 10 & 14 & 1 & 8 & 14 & 9 \\
\hline 2003 & 2 & 12 & 27 & & & & 2 & 10 & 14 & 1 & 8 & 15 & 10 \\
\hline 2004 & 2 & 12 & 28 & & & & 2 & 10 & 14 & 1 & 9 & 16 & 10 \\
\hline 2005 & 2 & 13 & 30 & $6^{*}$ & 9 & 19 & 2 & 9 & 14 & 1 & 9 & 17 & 10 \\
\hline 2006 & 2 & 13 & 31 & 6 & 10 & 20 & 2 & 9 & 14 & 1 & 9 & 18 & 10 \\
\hline 2007 & 2 & 13 & 32 & 6 & 9 & 19 & 2 & 10 & 16 & 1 & 10 & 19 & 10 \\
\hline
\end{tabular}

${ }^{*}$ Three sets of samples for acid- and alkali-impregnated filters and blank filters were sent;

** The soil extract solutions were sent to the laboratories in the 2001 project.

*** The trainees in the JICA Training Course participated in all the field exercises on soil, forest vegetation, and inland water. 
Table VIII. Frequency (\%) of data within DQOs after the EANET inter-laboratory exercises (after Network Center for EANET, 2008).

\begin{tabular}{|c|c|c|c|c|}
\hline Year & $\begin{array}{c}\text { Wet deposition (high) conc. } \\
(\%)\end{array}$ & $\begin{array}{c}\text { Wet deposition (low) conc. } \\
(\%)\end{array}$ & $\begin{array}{c}\text { Dry deposition } \\
(\%)\end{array}$ & $\begin{array}{c}\text { Inland aquatic environment } \\
(\%)\end{array}$ \\
\hline 1999 & 92.4 & 85.7 & & \\
\hline 2001 & 93.5 & 83.9 & & 88.6 \\
\hline 2002 & 86.2 & 70.3 & & 84.4 \\
\hline 2003 & 85.7 & 81.8 & & 81.2 \\
\hline 2006 & 93 & 83.9 & 91.5 & 79.7 \\
\hline 2007 & 93.4 & 85.9 & 81.8 & 86.8 \\
\hline
\end{tabular}

by the national QA/QC manager. All the data obtained in the previous year is expected to be submitted to Netwotk center (NC) by the end of June. The monitoring data submitted to NC is checked by ad hoc data verification groups, which consist of experts in the respective study fields. The verified data can be disclosed as the annual Data Report of EANET.

In addition to the $\mathrm{QA} / \mathrm{QC}$ programs above, the Senior technical managers' meeting is held annually to enable close communications. Such close communication with local experts of the countries helps to improve the quality of the data. Moreover, to share technical issues with surveyors or analysts in the respective countries, $\mathrm{NC}$ sends missions to the countries every one or two years.

\subsection{2. $Q A / Q C$ activity in field sampling and field surveys}

EANET does not have formal inter-calibration courses for field sampling and field surveys (soil, tree growth, species composition of the understorey vegetation). However, a part of the JICA Training Course may have some role on this issue. For soil sampling and assessment of forest vegetation monitoring (SV), one-day field training was conducted in addition to two-day lectures. In the field exercise for soil sampling soil profile descriptions, design of the sampling plots and subplots, and sampling procedures were practiced in the forest. The procedures on sampling and analysis were standardized by using the experience gained during these exercises. Most of the trainees are expected to work as key persons on sampling or analysis in the respective countries after the training courses. $\mathrm{NC}$ technical missions to the respective countries are also effective in order to share technical issues with surveyors or analysts.

It is worth noting that the statistical model proposed by the QA/QC for SV considered a multi-stage sampling design with several sampling levels, including area, soil type, plot, subplot, and horizon/layer, as follows:

$$
X=\mu+\theta+c+a+s+p+i+\varepsilon
$$

where $X$ is a measured value; $\mu$ is a mean value; and $\theta$ is the fixed effect of horizon on a soil profile, while there are random effects of country $(c)$, area $(a)$, soil type $(s)$, plot $(p)$, and subplot $(i)$, as well as $(\varepsilon)$, which is an error term under the repeatability condition. A variance at each sampling level and its contribution to the total variance could be estimated by the analysis of variance (ANOVA). This evaluation may permit to estimate the contribution of sampling to the total variance, to validate monitoring data and to improve sampling design. For example, the $\mathrm{pH}, \mathrm{Ex}-\mathrm{Ca}$, and $\mathrm{Ex}-\mathrm{Al}$ contents varied with soil type, and the Ex-Ca and Ex-Al contents with country, but they did not vary from area to area and plot to plot (EANET, 2006). Contribution of sampling at plot and subplot levels to the total variance was significantly small, 3-7\%.

\subsection{3. $Q A / Q C$ for laboratories}

NC promoted standardization of analytical procedures, and most laboratories have followed the standard procedures. Moreover, by using digital formats, calculation errors were reduced. Different interlaboratory comparison projects have been carried out (Tab. VII). Results revealed an increase of data within DQOs for wet deposition over the period 19982007, while for dry deposition and inland aquatic environment no clear trend is obvious (Network center for EANET, 2008) (Tab. VIII). For soil, the coefficient of variation (CVs, \%) was slightly improved compared with the early tests, although the CV of Ex-Ca was still relatively large (Network Center for EANET, 2008). Figure 4 shows the relationship between the sample concentrations and the inter-laboratories precision $(\mathrm{CV} \%)$ for $\mathrm{Ex}-\mathrm{Ca}$ and Ex-acidity in the past inter-laboratory comparison projects on soil. Ca concentrations in the samples may have large effects on the precisions: the CV\% for Ex-Ca was still large even in the latest results in 2006 compared with those for Ex-acidity.

\section{DISCUSSION}

There are some questions related to QA in EANET and ICP-Forests that deserve attention:

(i) Both programmes developed SOPs for the various investigations and considered training sessions. However, the various SOPs were not always consistent in terms of structure and issues covered. The coverage given to 

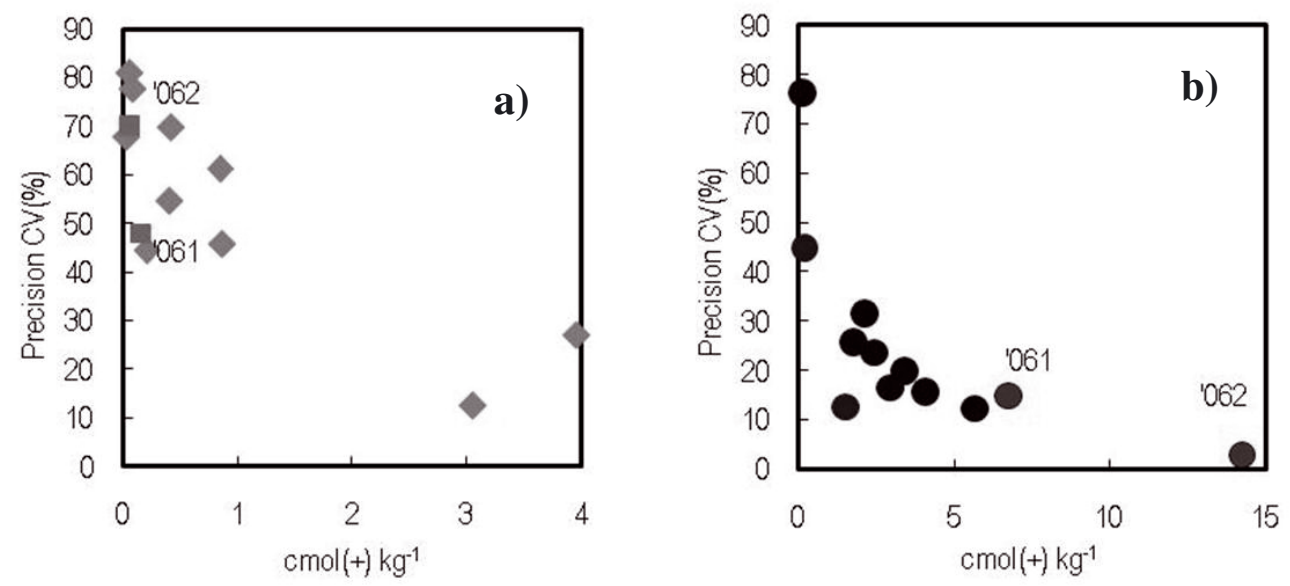

Figure 4. Relationship between the sample concentrations and the inter-laboratories precision (CV\%) for (a) exchangeable Ca and (b) exchangeable acidity in the past inter-laboratory comparison projects on soil. The numbers, '061 and '062, indicates the samples for the latest project in 2006.

QA/QC issues in the ICP-Forests Manual varies strongly among sub-manuals, and - for example - not all the investigation defined their own DQOs. In addition, while EANET formally requires participating Countries to develop national $\mathrm{QA} / \mathrm{QC}$ programmes, it is not so for the ICP-Forests.

(ii) Both programmes concentrated on the comparability of measurements, with special emphasis on crown condition (ICP-Forests) and chemical analyses (ICP-Forests and EANET). The activity in this field was valuable and permitted to document - and sometimes to control - measurement errors, which is an important component of the whole error budget of a given investigation (Köhl et al., 2000). Unfortunately, much less concern was given to other measurements (e.g. tree growth, assessment of ground vegetation and meteorological measurements) and these subjects should be improved in the future.

(iii) Field sampling was not properly addressed by the two programmes. This is unfortunate, as field sampling has been shown to account for the largest part of error in monitoring (e.g., Bargagli, 1998; Bleeker et al., 2003; Erisman, 2003; Kirvan et al., 2005). This goes together with the little attention given by both programmes in providing explicit and formal definition of monitoring objectives, in term of expected precision level of estimates and change/trend detection. A considerable effort is needed in this field.

(iv) Both programmes need to establish explicit links between the quality of sampling, the quality of measurement, and the quality of monitoring. Adequate sampling design and reliable measurement methods should go together, and should be well balanced in the overall monitoring design: sophisticated, time-consuming sampling design with imprecise, unreliable measurements will lead to a tremendous effort in the field and much error in the lab. On the other hand, even flawless analytical protocol will be use- less if the sampling design is biased and if field operations are carried out carelessly.

To achieve the above goals, it is important that (i) all the steps within the investigation are considered, not only the measurements, and (ii) all the investigations carried out within monitoring programmes are covered by QA in a comparable and standard format. In Europe (ICP-Forests), some efforts to make progress in this direction have been made recently: (i) the set up of the Working Group for Quality assurance and Quality Control in Laboratories (QA-QC Lab) and (ii) set up of the Quality Assurance Committee (QA-C). The QA-QC Lab consists of the leaders of the relevant expert groups dealing with laboratory analyses, ensure contacts with staff member of the various labs and co-ordinates activities aimed at ensuring high quality of analytical data. The QA-C (http://www. icp-forests.org/QAC.htm) is made up by the leaders of all the expert groups, coordinating centres and data managers: it aims at providing a common conceptual frame to harmonize the QA/QC approach within the ICP-Forests. Objectives, definitions, data quality requirements, data storage, processing and reporting will be covered by the activity of the group in a coordinated fashion.

\section{CONCLUSIONS}

The quality of monitoring is subject to many influences that need to be fully and formally considered when implementing current, and designing future, monitoring programmes. This is already acknowledged by funding agencies, and for example the US EPA requires that “... all work funded by EPA in which environmental data will be collected, evaluated, used, or reported ... have approved QA Project Plans" (EPA, 2002, p. 2). In the past several $Q A / Q C$ activities were carried out in Europe and East Asia, from the manual development to field observations and inter-laboratory comparisons, with particular emphasis on the analytical aspects. Other issues, like formal 
definition of objectives and field sampling has received so far much less attention. For this reason, it is not possible to assess the overall quality of monitoring, simply because monitoring objectives were never defined in operational terms. Building on the experience gained in the past, we believe that a more comprehensive QA approach is needed and this may apply also to many other international monitoring initiatives. Improving and documenting the quality of monitoring is not only possible, but also necessary. Failure in doing so will render results questionable, weaken the basis for decision making and disrupt the confidence in the role of science in environmental monitoring and management.

Acknowledgements: We are grateful to a number of colleagues that provide us data and info on past and current QA activity: Nathalie Cools (ICP Forests' Forest Soil Coordinating Centre) helped with data about past $\mathrm{QA} / \mathrm{QC}$ activity in soil chemical analyses; Alfred Fürst (ICP-Forests Forest Foliar Coordinating Centre) provided Figure 2 and data about past and current ring test for foliar analyses; Aldo Marchetto (CNR-ISE, Italy) dug out lots of information about past ring test for water chemistry. Egbert Beukert (Finnish Forest Research Institute - METLA), Stephan Raspe (Bavarian State Institute of Forestry - LWF) and Roberto Canullo (University of Camerino, Italy) provided information about QA/QC activity in Phenology, Meterology and Ground Vegetation; and Shinji Nakayama (QA/QC Manager of EANET, ADORC) provided information about QA/QC activities of EANET. We are in debt with National Focal Centres, labs and dozens of experts from many countries for the work they did in carrying out all the ring tests, intercalibration and intercomparisons exercises since the early stage of the programmes. We acknowledge the support of the COST Strategic Action for providing the support for the early stage of this paper. Finally, we would like to thank two anonymous referees for their helpful and stimulating comments.

\section{REFERENCES}

Bargagli R., 1998. Trace elements in terrestrial plants. AN ecophysiological approach to biomonitoring and biorecovery, Springer, Berlin, $324 \mathrm{p}$.

Bleeker A., Draaijers G.P.J., Bleeker A., van der Veen D., Erisman J.W., Moöls H., Fonteijn P., and Geusebroek M., 2003. Field intercomparison of throughfall and stemflow measurements performed within the framework of the Pan-European intensive monitoring program of EU/ICP Forests. Environ. Pollut. 125: 123-138.

Cline S.P. and Burkman W.G., 1989. The role of quality assurance in ecological programs. In: Bucher J.B. and Bucher-Wallin I. (Eds.), Air pollution and forest decline, Proc. 14th Int. Meeting for specialists on air pollution effects on forest ecosystems, IUFRO P2.05, Interlaken, Switzerland, Birmensdorf, pp. 361-365.

Cochran W.G., 1977. Sampling techniques, Third edition, John Whiley \& Sons, New York, NY, USA.

Cools N., Mikkelsen J.H., and De Vos B., 2007. Quality assurance and quality control in forest soil analysis: 5th FSCC interlaboratory comparison, Forest soil co-ordinating centre/INBO, Geraardsbergen, $63 \mathrm{p}$.

Cozzi A., Ferretti M., and Lorenz M., 2002. Quality assurance for crown condition assessment in Europe. Federal research centre for forestry and forest products-LINNÆA ambiente Srl, $111 \mathrm{p}$.

Di Stefano J., 2003. How much power is enough? Against the development of an arbitrary convention for statistical power calculations. Funct. Ecol. 17: 707-709.
Dobbertin M., Landmann G., Pierrat J.C., and Müller-Edzards C., 1997. Quality of crown condition data. In: C. Müller-Edzards, W. De Vries, and J.W. Erisman (eds), Ten years of monitoring forest condition in Europe. Studies on temporal development, spatial distribution and impacts of natural and anthropogenic stress factors. Technical background report. Geneva and Brussels, United nations economic commission for Europe/European commission, pp. 7-22.

Draaijers G.P.J., Bleeker A., van der Veen D., Erisman J.W., Mols J., Fonteijn P., and en Geusebroek M., 2001. Field intercomparison of throughfall, stemflow and precipitation measurements performed within the framework of the Pan European intensive monitoring program of EU/ICP forests (TNO report R 2001/140) TNOMEP, Apeldoorn.

EANET (2000). QA/QC for Soil and vegetation monitoring in East Asia. Acid Deposition and Oxidant Research Center, Niigata, Japan. EANET publications, acid deposition monitoring network in East Asia. http://www.eanet.cc/product.html

EANET (2008). Periodic report on the state of acid deposition in East Asia. Acid deposition and oxidant research center, Niigata, Japan. EANET publications, Acid deposition monitoring network in East Asia. http://www.eanet.cc/product.html

Elzinga C.L., Salzer D.W., Willoughby J.W., and Gibbs J.P., 2001. Monitoring plant and animal population. Blackwell science, Malden, Massachussets, USA, $337 \mathrm{p}$.

EPA, 2002. Guidance for quality assurance project plans, EPA QA/G-5, EPA/240/R-02/009, United States environmental protection agency, Washington, $111 \mathrm{p}$ (www.epa.gov/quality/qs-docs/g5-final.pdf).

Erisman J.W., Möls J., Fonteijn P., Geusebroek M., Draaijers G.P.J., Bleeker A., and van der Veen D., 2003. Field intercomparison of precipitation measurements performed within the framework of the PanEuropean Intensive monitoring program of EU/ICP forests, Environ. Pollut. 125: 139-155.

Ferretti M. (Ed.), 2009. Quality assurance in ecological monitoring. J. Environ. Monit. 11: 726-729.

Ferretti M., 2004. Forest health diagnosis, monitoring and evaluation. In: Burley J., Evans J., and Youngquist J. (Eds.), Encyclopedia of forest sciences, Elsevier science, London: 285-299.

Ferretti M., 1997. Forest health assessment and monitoring. Issues for consideration. Environ. Monit. Assess. 48: 45-72.

Ferretti M. and Mues V., 2002. New design of international crosscalibration courses of ICP forests and the EU scheme. Federal research centre for forestry and forest products (BFH) -LINNÆA ambiente $\mathrm{Srl}, 21 \mathrm{p}$.

Field S.A., Tyre A.J., Jonzén N., Rhodes J.R., and Possingham H.P., 2004. Minimizing the cost of environmental decision by optimizing statistical thresholds. Ecol. Lett. 7: 669-675.

Fürst A., 2008. 10th needle/leaf interlaboratory comparison test 2007/2008, Forest foliar coordinating centre/BFW, Vienna, 110 p.

Gasparini P., Bertani R., De Natale F., Di Como L., and Pompei E., 2009. Quality control procedures in the Italian national forest inventory. J. Environ. Monit. 11: 761-768.

Gutachterausschuss Forstliche Analytik (Herausgeber), 2005. Handbuch forstliche analytik (http://www.bmelv.de/cln_044/ nn_753670/DE/06-Forstwirtschaft/Bodenzustandserhebung/ HandbuchForstlicheAnalytik.html).

Houston T.J., Durrant D.W., and Benham S.E., 2002. Sampling in a variable environment: selection of representative positions of throughfall collectors for volume and chemistry under three tree species in the UK. For. Ecol. Manage. 158: 1-8.

Innes J.L., 1988. Forest health surveys: problems in assessing observer objectivity. Can. J. For. Res. 18: 560-565.

Innes J.L., 1993. Forest health: its assessment and status. Commonwealth agricultural bureau, Wallingford, $677 \mathrm{p}$. 
Innes J.L., Landmann G., and Mettendorf B., 1993. Consistency of observation of forest tree defoliation in three european countries. Environ. Monit. Assess. 25: 29-40.

Innes J.L., Landmann G., and Mettendorf B., 1993. Consistency of observation of forest tree defoliation in three European countries, Environ. Monit. Assess. 25: 29-40.

Kaufmann E. and Schwyzer A., 2001. Control survey of the terrestrial inventory. In: Brassel P. and Lischke H. (Eds.), Swiss national forest inventory: methods and models of the second assessment, WSL Swiss federal research institute, Birmensdorf, pp. 114-124.

Kirvan N., Oliver M.A., Moffat A.J., and Morgan G.W., 2005. Sampling the soil in long-term forest plots: the implications of spatial variation. Environ. Monit. Assess. 111: 149-172.

Kitahara F., Mizoue N., and Yoshida S., 2008. submitted. Evaluation of data quality in Japanese forest inventory. Environ. Monit. Assess. DOI: $10.1007 / \mathrm{s} 10661-008-0632-8$.

Köhl M., Innes J.L., and Kaufmann E., 1994. Reliability of differing densities of sample grids used for the monitoring of forest condition in Europe., Environ. Monit. Assess. 29: 201-220.

Köhl M., Traub B., and Päivinen R., 2000. Environ. Monit. Assess. 63: $361-380$.

König N. and Wolff B. 1993. Abschlussbericht über die Ergebnisse und Konsequenzen der im Rahmen der bundesweiten Bodenzustandserhebung im WALD (BZE) durchgeführten Ringanalysen. Ber. Forsch. Waldökosysteme B 33: 1-33.

Legg C. and Nagy L., 2006. Why most conservation monitoring is, but need not be, a waste of time. J. Environ. Manage. 78: 194-199.

Mapstone B.D.. 1995. Scalable decision rules for environmental impact studies: effects size, Type I, and II errors. Ecol. Appl. 5: 401-410.

Marchetto A., Mosello R., Tartari G., Derome J., Derome K., Sorsi P., König N., Clarke N., Ulrich E., and Kowalska A., 2006. Atmospheric deposition and soil solution working ring test 2005 - Laboratory ring test for deposition and soil solution sample analyses between the countries participating in the ICP Forests level II monitoring programme. Office national des forêts, Département recherche, Fontainebleau, $85 \mathrm{p}$.

Mizoue N., Dobbertin M., 2003. Detecting differences in crown transparency assessments between countries using the image analysis system CROCO. Environ. Monit. Assess. 89: 179-195.

Mosello R., Derome J., Derome K., Ulrich E., Dahlin T., Marchetto A., and Tartari G., 2002. Atmospheric deposition and soil solution Working Ring Test 2002 - Laboratory ring test for deposition and soil solution sample analyses between the countries participating in the ICP Forests level II monitoring programme, Office national des forêts, Département recherche et développement, Fontainebleau, $69 \mathrm{p}$.

Mosello R., Bianchi M., Geiss H., Marchetto A., Serrini G., Serrini Lanza G., Tartari G.A., and Muntau H., 1997. AQUACONMedBas Subproject No. 6. Acid rain analysis. Intercomparison 1/96, European commission joint research centre, Ispra, $47 \mathrm{p}$.

Mosello R., Bianchi M., Brizzio M.C., Geiss H., Leyendecker W., Marchetto A., Serrini G., Serrini Lanza G., Tartari G.A., and Muntau H., 1998. AQUACON-MedBas Subproject No. 6. Acid rain analysis. Intercomparison 1/97, European commission joint research centre, Ispra, $65 \mathrm{p}$.

Mosello R., Bianchi M., Brizzio M.C., Geiss H., Leyendecker W., Marchetto A., Rembges D., Tartari G.A., and Muntau H., 1999. AQUACON-MedBas Subproject No. 6. Acid rain analysis. Intercomparison 1/98, European commission joint research Centre, Ispra, $81 \mathrm{p}$.
Mosello R., Bianchi M., Brizzio M.C., Giuliano R., Marchetto A., Rembges D., Tartari G.A., and Muntau H., 2001. Analytical Quality Control and assessment Studies in the Mediterranean Basin. Subproject 5, Freshwater analysis, Intercomparison 1/00. Results of the ICP Forests laboratories. In: Rembges D. and Geiss O. (Eds.), Proceedings of the workshop: Quality assurance and quality control in laboratory performing the deposition analyses of the Pan European programme of intensive monitoring of forest ecosystems in Ispra, EUR 20112 En, European commission joint research centre and ICP forests, Ispra, pp. 36-76.

Mues V., 2006. Results of the international cross-comparison courses 2005, programme co-ordinating centre of ICP Forests, BFH, Hamburg, 37 p. (http://www.icp-forests.org/pdf/ICC2005.pdf).

Network Center for EANET (2008). Report on the inter-laboratory comparison project 2007. Acid deposition and oxidant research center.

Palmer C.J., 1992. The 1992 quality assurance annual report and workplan for the interagency forest health monitoring program. TIP \# 92-295. Research triangle Park, NC: U.S. environmental protection agency, Office of research and development.

Parr T.W., Ferretti M., Simpson I.C. , Forsius M., and Kovács-Láng E., 2002. Towards a long-term integrated monitoring programme in Europe: Network design in theory and practice. Environ. Monit. Assess. 78: 253-290.

Peterman R.M., 1990. The importance of reporting statistical power: the forest decline and acidic deposition example. Ecology 71: 20242027.

Pollard J.E., Westfall J.A., Patterson P.L., Gartner D.L., Hansen M., and Kuegler O., 2006. Forest inventory and analysis national data quality assessment report for 2000 to 2003. Gen. Tech. Rep. RMRS-GTR181. Fort collins, CO: U.S. Department of agriculture, forest service, Rocky mountain research station. $43 \mathrm{p}$.

Shampine W.J., 1993. Quality assurance and quality control in monitoring programs. Environ. Monit. Assess. 26, 143-151.

Stevens D., 1994. Implementation of a national monitoring program. J. Environ. Manag. 42: 1-29.

Sulkava M., Luyssaert S., Rautio P., Janssens I.A., and Hollmén J., 2007. Modeling the effects of varying data quality on trend detection in environmental monitoring. Ecol. Inform. 2: 167-176.

Task Force on Soil and Vegetation Monitoring of EANET, 2006. Submanual on forest vegetation monitoring in EANET. Acid deposition and oxidant research center, Niigata, Japan.

Thimonier A., 1998: Measurement of atmospheric deposition under forest canopies: some recommendations for equipment and sampling design. In: Environ. Monit. Assess. 53: 353-387.

UN-ECE, 2004. International co-operative programme on assessment and monitoring of air pollution effects on forests. Manual on methods and criteria for harmonized sampling, assessment, monitoring and analysis of the effects of air pollution on forests. United nations economic commission for Europe, Convention on long-range transboundary air pollution. With eleven parts (http://www.icp-forests.org/Manual. htm).

UN/ECE, 2007. The condition of forests in Europe, 2007 executive report, ICP forests and European commission, Hamburg and Brussels, $33 \mathrm{p}$.

Vos P., Meelis E., and Ter Keurs W.J., 2000. A framework for the design of ecological monitoring programs as a tool for environmental and nature management. Environ. Monit. Assess. 61: 317-344, 2000.

Wagner G., 1995. Basic approaches and methods for quality assurance and quality control in sample collection and storage for environmental monitoring. The Science of Total Environment 176: 63-71. 